\title{
POLA BAKTERI INFEKSI SALURAN KEMIH DI POLIKLINIK KULIT DAN KELAMIN BLU RSUP PROF. Dr. R. D. KANDOU MANADO PERIODE NOVEMBER 2010 - NOVEMBER 2012
}

\author{
${ }^{1}$ Ayu R. Melati \\ ${ }^{2}$ John Porotu'o \\ ${ }^{2}$ Fredine E. S. Rares
}

\author{
${ }^{1}$ Kandidat Skripsi Fakultas Kedokteran Universitas Sam Ratulangi Manado \\ ${ }^{2}$ Bagian Mikrobiologi Fakultas Kedokteran Universitas Sam Ratulangi Manado \\ Email: ayumelati09@yahoo.com
}

\begin{abstract}
Urinary tract of human are the organs that work to collect and store urine, organs that secrete the urine from the body, the kidneys, ureters, bladder and urethra. In general, females have more frequent episodes of urinary tract infection (UTI) than males. Moreover, sexual intercourse can cause a UTI because due to the mechanical process bacteria can enter the urinary tract during sexual intercourse. This study aimed to determine the pattern of bacteria in patients with UTI in the Dermatology Clinic. This was a retrospective descriptive study carried out in November 2012 - January 2013 in the Department of Dermatology Clinic at Prof. Dr. R. D. Kandou Hospital, Manado. There were 36 samples with UTI. The result showed that the highest percentage of UTI in the age group 16-26 years (41.7\%) and male gender 31 people $(86.1 \%)$. Based on the laboratory test, $31 \%$ were found with positive results and $69 \%$ with negative results of diplococcus gram-positive bacteria. Conclusion: Based on the laboratory examination and the bacteria found UTIs were more frequent among males of age group 16-26 without diplococcus Gram positive.
\end{abstract}

Keywords: age, gender, laboratory test

\begin{abstract}
Abstrak: Saluran kemih manusia merupakan organ-organ yang bekerja untuk mengumpul dan menyimpan urin serta organ yang mengeluarkan urin dari tubuh, yaitu ginjal, ureter, kandung kemih dan uretra. Pada umumnya wanita lebih sering mengalami episode infeksi saluran kemih (ISK) daripada pria. Diketahui bahwa hubungan seksual dapat menyebabkan ISK. Hal ini sebagian besar dianggap sebagai proses mekanis dimana bakteri masuk ke dalam saluran kemih selama melakukan hubungan seksual. Penelitian ini bertujuan untuk mengetahui pola bakteri pada pasien ISK di Poliklinik Kulit dan Kelamin. Metode yang digunakan ialah deskriptif retrospektif. Penelitian dilaksanakan pada bulan November 2012 - Januari 2013 bertempat di Poliklinik Kulit dan Kelamin BLU RSUP Prof. Dr. R. D. Kandou Manado. Sampel yang diperoleh 36 orang. Berdasarkan umur, jenis kelamin dan hasil pemeriksaan laboratorium, Isk terbanyak ditemukan pada kelompok umur 16-26 tahun (41,7\%), jenis kelamin laki-laki 31 orang $(86,1 \%)$, dan bakteri diplokokus gram (-) yang positif pada $31 \%$ sampel. Simpulan: Berdasarkan hasil pemeriksaan laboratorium dan bakteri yang ditemukan ISK lebih sering ditemukan pada laki-laki berumur 16-26 tahun tanpa diplokokus Gram positif.
\end{abstract}

Kata kunci: umur, jenis kelamin, pemeriksaan laboratorium

Infeksi saluran kemih (ISK) adalah infeksi akibat berkembang biaknya mikroorganisme di dalam saluran kemih. Dalam keadaan normal air kemih tidak mengandung bakteri, virus atau mikroorganisme. ${ }^{1}$ Saluran kemih manusia merupakan organ-organ yang bekerja untuk mengumpul dan menyimpan urin serta 
organ yang mengeluarkan urin dari tubuh, yaitu ginjal, ureter, kandung kemih dan uretra. Menurut National Kidney and Urologic Diseases Information Clearinghouse (NKUDIC), ISK merupakan penyakit infeksi kedua tersering setelah infeksi saluran pernafasan dan sebanyak 8,1 juta kasus dilaporkan per tahun. ${ }^{2}$

Pada umumnya wanita lebih sering mengalami episode ISK daripada pria. Namun, pada masa neonatus ISK lebih banyak terjadi pada bayi laki-laki $(2,7 \%)$ yang tidak menjalani sirkumsisi daripada bayi perempuan (0,7\%). Dengan bertambahnya usia, insiden ISK terbalik yaitu pada masa sekolah ISK pada anak perempuan 3\%, sedangkan anak laki-laki $1,1 \%$. Insiden ISK ini pada remaja anak perempuan meningkat 3,3 sampai $5,8 \%{ }^{3}$

Menurut Loynd dan Rosh, dalam artikel di Emedicine - Urinary Tract Infection in Pregnancy, di Amerika Serikat, sebanyak 2-7\% dari ibu hamil terkena ISK dan sebanyak $40 \%$ daripadanya terkena bakteriuria asimptomatik. Beberapa penelitian juga dilakukan di seluruh dunia dan angka kejadian terjadinya ISK bervariasi antara penelitian satu dengan yang lain. ${ }^{4}$

Diketahui bahwa hubungan seksual dapat menyebabkan ISK. Hal ini sebagian besar dianggap sebagai proses mekanis dimana bakteri masuk ke dalam saluran kemih selama melakukan hubungan seksual. Tidak ada kejanggalan tentang transmisi ISK yang disebabkan oleh organisme penyakit menular seksual (PMS) (misalnya, gonore dan klamidia) mudah terjangkit kepada pasangan seks dan sangat menular. $^{5}$

\section{METODE PENELITIAN}

Penelitian ini menggunakan metode deskriptif retrospektif, yaitu suatu metode yang digunakan dalam penelitian yang berdasarkan pengumpulan data yang nantinya akan diolah menurut beberapa variable agar tercapainya suatu validitas data. Penelitian dilaksanakan pada bulan November 2012 - Januari 2013 dan penelitian dilakukan di Poliklinik Kulit dan Kelamin BLU RSUP Prof. Dr. R. D. Kandou, Manado. Populasi penelitian adalah semua pasien rawat jalan di Poliklinik Kulit dan Kelamin BLU RSUP Prof. Dr. R. D. Kandou Manado periode November 2010 - November 2012.

Sampel penelitian adalah semua pasien yang datang di Poliklinik dengan keluhan nyeri buang air kecil, keluar cairan putih kekuningan, nyeri pinggang bagian bawah, dan atau hematuria. Sampel yang memenuhi kriteria inklusi adalah pasien dengan keluhan nyeri buang air kecil, keluar cairan putih kekuningan, nyeri pinggang bagian bawah, dan atau hematuria yang datang ke Poliklinik Kulit dan Kelamin yang dilakukan pemeriksaan laboratorium, dan sampel penelitian yang memenuhi kriteria eksklusi semua pasien yang datang dengan keluhan nyeri buang air kecil, keluar cairan putih kekuningan, nyeri pinggang bagian bawah, dan atau hematuria di Poliklinik Kulit dan Kelamin BLU RSUP Prof. Dr. R. D. Kandou Manado. Dalam penelitian ini variabel yang akan di teliti: jenis kelamin (laki-laki dan perempuan), usia ( $\leq 19-69$ tahun) serta hasil pemeriksaan laboratorium.

\section{HASIL PENELITIAN}

Berdasarkan penelitian yang dilakukan di Poliklinik Kulit dan Kelamin BLU RSUP Prof. Dr. R. D. Kandou Manado periode November 2010 - November 2012 maka ditemukan 18 pasien $(50,0 \%)$ didiagnosis Gonorrheae, 13 pasien $(36,1 \%)$ didiagnosis Urethritis Gonorrheae, 4 pasien $(11,1 \%)$ didiagnosis NonGonococcal Urethritis, 2 pasien $(5,6 \%)$ didiagnosis IGNS, 1 pasien $(2,8 \%)$ didiagnosis Erosi penis, 1 pasien $(2,8 \%)$ didiagnosis Bacterial Vaginosis yang dilakukan pemeriksaan Gram di laboratorium. 
Tabel 1. Distribusi Berdasarkan Karakteristik Pasien di Poliklinik Kulit dan Kelamin BLU RSUP Prof. Dr. R. D. Kandou Manado

\begin{tabular}{|c|c|c|}
\hline Karakteristik Pasien & Jumlah & Persentase $(\%)$ \\
\hline \multicolumn{3}{|l|}{ Jenis kelamin } \\
\hline - Laki-laki & 31 & 86,1 \\
\hline - Perempuan & 5 & 13,9 \\
\hline \multicolumn{3}{|l|}{ Usia } \\
\hline - 16-26 tahun & 15 & 41,7 \\
\hline - 27-34 tahun & 8 & 22,2 \\
\hline - 35-40 tahun & 6 & 16,7 \\
\hline - 41-67 tahun & 7 & 19,4 \\
\hline \multicolumn{3}{|l|}{ Diagnosis } \\
\hline - Gonore & 18 & 50,0 \\
\hline - Bakterial Vaginalis & 1 & 2,8 \\
\hline - Uretritis Gonore & 13 & 36,1 \\
\hline - Erosi Penis & 1 & 2,8 \\
\hline - $\quad$ IGNS & 2 & 5,6 \\
\hline - $\mathrm{NGU}$ & 4 & 11,1 \\
\hline
\end{tabular}

Pada tabel 1 didapatkan hasil jenis kelamin laki-laki 31 orang $(86,1 \%)$, perempuan 5 orang $(13,9 \%)$, usia $16-26$ tahun 15 orang (41,7\%), 27-34 tahun 8 orang (22,2), 35-40 tahun 6 orang $(16,7 \%), 41-57$ tahun 7 orang $(19,4 \%)$, diagnosis gonore 18 orang $(50,0 \%)$, bakterial vaginalis 1 orang
$(2,8 \%)$, urethritis gonore 13 orang $(36,1 \%)$, erosi penis 1 orang $(2,8 \%)$, IGNS (infeksi genital non spesifik) 2 orang $(5,6 \%)$, dan NGU (non-gonore urethritis) 4 orang $(11,1 \%)$.

Tabel 2. Distribusi berdasarkan hasil pewarnaan gram di Poliklinik Kulit dan Kelamin BLU RSUP Prof. Dr. R. D. Kandou Manado

\begin{tabular}{lcccc}
\hline & Positif & \multicolumn{3}{c}{ Negatif } \\
\hline & $\mathrm{N}$ & $\%$ & $\mathrm{~N}$ & $\%$ \\
Diplokokus gram (+) & 7 & 19,4 & 29 & 80,6 \\
Diplokokus gram (-) & 11 & 30,6 & 25 & 69,4 \\
Basil gram (+) & 1 & 2,8 & 35 & 97,2 \\
\hline
\end{tabular}


Melati, Porotu'o, Rares: Pola bakteri infeksi ...

\begin{tabular}{lllll}
\hline Basil gram (-) & 9 & 25,0 & 27 & 75,0
\end{tabular}

Pada tabel penelitian diatas ditemukan Diplokokus gram (+) yang hasilnya positif sebanyak 7 pasien (19\%), Diplokokus gram (+) yang hasilnya negatif sebanyak 29 pasien (81\%), Diplokokus gram (-) yang hasilnya positif terdapat 11 pasien $(31 \%)$, Diplokokus garm (-) yang hasilnya negatif terdapat 25 pasien (69\%), yaitu Basil gram (+) yang hasilnya positif terdapat 1 pasien (28\%), dan Basil gram (+) yang hasilnya negatif terdapat 35 pasien $(72 \%)$, Basil gram (-) yang hasilnya positif terdapat 9 pasien $(25,0 \%)$ dan Basil gram (-) yang hasilnya negatif terdapat 36 pasien $(75,0 \%)$.

\section{BAHASAN}

Kriteria sampel yang diteliti merupakan pasien rawat jalan dengan keluhan nyeri buang air kecil, nyeri pinggang bagian bawah, keluar cairan putih pada kelamin, dan atau hematuria yang dimana gejala tersebut dapat menyebabkan ISK dengan dilakukan pemeriksaan Gram di Bagian Poliklinik Kulit dan Kelamin BLU RSUP Prof. Dr. R. D. Kandou Manado periode November 2010 November 2012, sebanyak 18 pasien (50,0\%) didiagnosis Gonorrhoeae, 13 pasien $(36,1 \%)$ didiagnosis Urethritis Gonorrhoeae, 4 pasien $(11,1 \%)$ didiagnosis Non-Gonococcal Urethritis, 2 pasien $(5,6 \%)$ didiagnosis infeksi genital nonspesifik (IGNS), 1 pasien $(2,8 \%)$ didiagnosis erosi penis, 1 pasien $(2,8 \%)$ didiagnosis Bacterial Vaginalis.

Berdasarkan hasil yang didapatkan, pada penelitian ini terdapat pasien laki-laki sebanyak 31 orang $(86,1 \%)$, dan perempuan sebanyak 5 orang $(13,9 \%)$. Wanita tercatat lebih sedikit menderita GO daripada laki-laki. Hal ini disebabkan $80 \%$ perempuan tidak mengeluh adanya gejala, sementara pada laki-laki yang terinfeksi, jarang yang tidak menunjukkan gejala. Hanya 3-40\% dari penderita yang tidak memberi gejala klinis, dengan demikian berpotensi sebagai sumber penularan. ${ }^{6,7}$
Berdasarkan distribusi kelompok umur, pada penelitian ini didapatkan hasil terbanyak pada kelompok umur 16 - 26 tahun $(41,7 \%)$, dan paling sedikit pada kelompok umur 35 - 40 tahun $(16,7 \%)$. Seperti yang disebutkan oleh Lukman $\mathrm{H}$. pada penelitiannya tentang Epidemiologi Infeksi Menular Seksual di Malang bahwa yang disebutkan sebagai kelompok perilaku risiko tinggi dalam PMS ialah perilaku yang menyebabkan seseorang mempunyai risiko besar terserang penyakit, dan jika di lihat dari segi usia, maka tergolong kelompok risiko tinggi adalah 20-24 tahun. Sedangkan di Amerika, insiden terbanyak pada usia 15-24 tahun, hal ini dikaitkan dengan bertambahnya jumlah pasangan seksual. ${ }^{6}$

Berdasarkan distribusi pasien tersebut menurut mikroorganisme penyebab didapati bahwa diplococcus gram (+) dengan hasil positif terdapat 7 pasien (19\%), diplococcus gram (+) dengan hasil negatif terdapat 29 pasien $(81 \%)$, diplococcus gram (-) dengan hasil positif terdapat 11 pasien (31\%), diplococcus gram (-) dengan hasil negatif terdapat 25 pasien (69\%), basil gram (+) dengan hasil positif terdapat 1 pasien (28\%), basil gram (+) dengan hasil negatif terdapat 35 pasien (72\%), basil gram (-) dengan hasil positif terdapat 9 pasien $(25,0 \%)$, dan basil gram (-) dengan hasil negatif terdapat 27 pasien $(75,0 \%)$ merupakan organisme tersering yang menyebabkan Gonorrhoeae dan Urethritis Gonorrhoeae, dimana aktif secara seksual bisa terjadi ISK apabila organisme penyakit menular seksual (PMS) masuk kedalam saluran kemih selama melakukan hubungan seksual. Gonorrhoeae biasanya terjadi dengan uretritis (infeksi uretra). Ini adalah salah satu penyebab yang lebih umum dari ISK berulang karena transmisi seksual.

Di Indonesia, dari data yang diambil dari beberapa RS bervariasi. Di klinik IMS RS. Dr. Soetomo antara Januari 1990 Desember 1993 terdapat 3055 kasus 
uretritis atau $25,22 \%$ dari total IMS dan 1853 atau $60,65 \%$ diantaranya menderita UGO, di RS. Kariadi Semarang, GO menempati urutan ke 3 atau sebesar $17,56 \%$ dari seluruh penderita IMS tahun 1990-1994, dan di RSUP Palembang prevalensi GO sebesar 39\% pada tahun 1990. Sedangkan penelitian yang dilakukan oleh Fitri A. J. dan Dwi M. pada penderita GO di divisi Penyakit Menular Seksual URJ Penyakit Kulit dan Kelamin RSU Dr. Soetomo Surabaya periode 2002-2006 didapatkan hasil, yaitu $321(0,94 \%) .{ }^{6,8}$ Dari penelitian tersebut terdapat perbedaan dengan prevalensi terjadinya GO dan UGO di Poliklinik BLU RSUP Prof. Dr. R. D. Kandou Manado periode November 2010 November 2012, yaitu pasien yang terdiagnosis GO terdapat 47,2\% dan UGO $27,8 \%$.

Data tersebut menunjukkan bahwa insiden GO sangat bervariasi akibat pengaruh kondisi sosial budaya setempat, fasilitas, pelayanan kesehatan dan metode penelitian yang digunakan. ${ }^{8}$

\section{SIMPULAN}

Pola bakteri Infeksi Saluran Kemih di Poliklinik Kulit dan Kelamin BLU RSUP Prof. Dr. R. D. Kandou Manado periode November 2010 - November 2012 dapat disimpulkan sebagai berikut :

1. Kelompok umur tersering yang mengalami keluhan nyeri saat buang air kecil dan keluar cairan putih kekuningan adalah 16 -57 tahun.

2. Laki-laki lebih sering mengalami keluhan tersebut dibanding perempuan.

3. Pola bakteri yang menyebabkan gejalagejala tersebut adalah Diplokokus gram (+), Diplokokus gram (-), Basil gram (+), dan Basil gram (-).

4. Bakteri yang paling sering menyebabkan gejala-gejala tersebut adalah Diplokokus gram (-).

\section{SARAN}

1. Bagi dokter dan tenaga medis yang bergerak dalam bidang pelayanan, kiranya dapat mencantumkan hasil pemeriksaan laboratorium yang dilakukan setiap pasien dengan jelas, rapi, dan teratur.

2. Pasien yang diduga menderita Gonorrhoeae, Urethritis Gonorrhoeae dan Non-Gonococcal Urethritis yaitu infeksi menular seksual tersering yang dapat menyebabkan terjadinya ISK sebaiknya selalu dilakukan pemeriksaan laboratorium sehingga hasil dari bakteri penyebab dapat diketahui dengan pasti.

3. Setiap pasien yang diduga maupun terdiagnosis Gonorrhoeae, Urethritis Gonorrhoeae dan Non-Gonococcal Urethritis harus melakukan kontrol rutin dan menjalankan pengobatan secara teratur untuk mencegah terjadinya komplikasi.

\section{UCAPAN TERIMA KASIH}

Terima kasih kepada Prof. dr. H. Pandeleke, MSc, Sp KK (K) selaku penguji I dan dr. Standy Soeliongan, MRepro, SpMK (K) selaku penguji II dan semua pihak yang secara langsung dan tidak langsung telah menumbuhkan ide atau gagasan sehingga penulis dapat menyelesaikan tulisan ini.

\section{DAFTAR PUSTAKA}

1. Samira, Darwati, Windarwati, Hardjoeno. Pola dan sensitifitas kuman di penderita infeksi saluran kemih di bagian patologi klinik. FK. UNHAS/RS. Wahidin Sudirohusodo, Makassar, 110.

2. Griebling TL. Urinary Tract Infection in Adults. Department of Health and Human Services, Public Health Service, National Institutes of Health.. National Institute of Diabetes and Digestive and Kidney Diseases. Washington, D. C: GPO; 2007.

3. Purnomo BB. Dasar-Dasar Urologi $3^{\text {rd }}$ Edition. Jakarta: Sagung Seto, 201; p. 52.

4. Jhonson EK, MD. Chief Editor: Kim ED, MD, FASC. Urinary Tract Infection in Pregnancy. In Medscape. Update: Apr 11, 2012. 
Melati, Porotu'o, Rares: Pola bakteri infeksi ...

5. Davis CP. Urine Infection. Editor: Balentine JR. Available from : URL: http://www.medicinenet.com/urine_inf ection/page2.htm. (cited 2012 Oct 29).

6. Jawas F. A, Murtiastutik D. Penderita Gonore di Divisi Penyakit Menular Seksual Unit Rawat Jalan Ilmu Kesehatan Kulit dan Kelamin RSU Dr. Soetomo Surabaya Tahun 2002-2006. FK UNAIR/RSU Dr. Soetomo, Surabaya. p. 218-20.

7. Josodiwondo S. Kokus Gram Negatif. dalam Buku Ajar Mikrobiologi Kedokteran. Edisi Revisi. Staf Pengajar Fakultas Kedokteran Universitas Indonesia. p. 149.

8. Hakim L. EPIDEMIOLOGI INFEKSI MENULAR SEKSUAL. Bagian Ilmu Kesehatan Kulit dan Kelamin Universitas Brawijaya, Malang. dalam INFEKSI MENULAR SEKSUAL. Edisi keempat. Penerbit buku FKUI, Jakarta. p. 7-8. 